\title{
Non-invasive cardiac imaging of coronary artery anomalies
}

Citation for published version (APA):

Gräni, C. (2018). Non-invasive cardiac imaging of coronary artery anomalies. [Doctoral Thesis, Maastricht University]. Datawyse / Universitaire Pers Maastricht. https://doi.org/10.26481/dis.20180223cg

Document status and date:

Published: 01/01/2018

DOI:

$10.26481 /$ dis.20180223cg

Document Version:

Publisher's PDF, also known as Version of record

\section{Please check the document version of this publication:}

- A submitted manuscript is the version of the article upon submission and before peer-review. There can be important differences between the submitted version and the official published version of record.

People interested in the research are advised to contact the author for the final version of the publication, or visit the DOI to the publisher's website.

- The final author version and the galley proof are versions of the publication after peer review.

- The final published version features the final layout of the paper including the volume, issue and page numbers.

Link to publication

\footnotetext{
General rights rights.

- You may freely distribute the URL identifying the publication in the public portal. please follow below link for the End User Agreement:

www.umlib.nl/taverne-license

Take down policy

If you believe that this document breaches copyright please contact us at:

repository@maastrichtuniversity.nl

providing details and we will investigate your claim.
}

Copyright and moral rights for the publications made accessible in the public portal are retained by the authors and/or other copyright owners and it is a condition of accessing publications that users recognise and abide by the legal requirements associated with these

- Users may download and print one copy of any publication from the public portal for the purpose of private study or research.

- You may not further distribute the material or use it for any profit-making activity or commercial gain

If the publication is distributed under the terms of Article $25 \mathrm{fa}$ of the Dutch Copyright Act, indicated by the "Taverne" license above, 


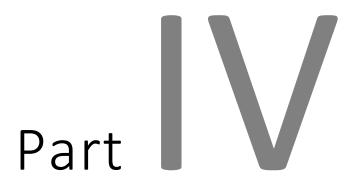

Summary (in English) and Samenvatting

(Summary in Dutch) 



\section{Summary English}

In the introduction section, an overview of coronary artery anomalies (CAAs) and current issues and the possible role of non-invasive imaging is presented. CAAs consist of a group of congenital disorder which can be divided into anomalies with an abnormal origin of the vessel, abnormal course of the vessel or abnormal termination of the vessel. The prevalence of CAA in the general population is low and estimated to be around one percent. Although most individuals with CAA are undetected as the CAA is clinically insignificant, some individuals and especially those with certain variants of CAAs, (nameIy anomalous coronary artery from the opposite sinus of Valsalva, ACAOS) may become symptomatic and experience adverse cardiac events. Particularly young athletes with ACAOS are considered to be at risk for sports-related sudden cardiac death (SCD). Beside the young individuals involved in sports and diagnosed with CAAs, a larger rate of coincidentally detected CAAs, especially in the middle-aged and elderly population with the increasing use of non-invasive imaging for the exclusion of coronary artery disease (CAD), is expected. The presented research focuses on the incidence of sports-related SCD with underlying CAAs and what role non-invasive imaging plays in the assessment and guidance for the treatment of individuals with CAAs.

Chapter 2.1 discusses the issue of sports-related SCD in young athletes. We were interested in the assessment of the incidence and characteristics of sports-related SCD and in the underlying causes of sports-related SCD including CAAs. We therefore analyzed retrospectively the forensic reports of sports-related SCD in young individuals in Switzerland. Data were compared to the sports participation behavior of the Swiss population. In a total of sixty-nine sports-related SCD, CAD was the most common underlying pathology of sports-related SCD, followed by hypertrophic cardiomyopathy and "unremarkable findings" at autopsy. CAAs were only diagnosed in a very few number of autopsies. This is in contrary to other older reports where autopsy series showed that after hypertrophic cardiomyopathies, CAAs were the second most underlying cause of sports-related SCD. Our findings might underline more recent reports, that the numbers of sports-related SCD associated with CAAs might be overestimated.

In Chapter 2.2 we present a single center study, looking at prevalence, incidence and characteristics of CAA detected by coronary computed tomography angiography (CCTA). CAAs were retrospectively sought in 5634 consecutive patients referred for CCTA. We identified 145 patients with CAA resulting in an overall prevalence of $2.6 \%$ and cumulative incidence of $2.1 \%$ in all patients referred for CCTA in the observed period. The prevalence of CAAs detected by CCTA is therefore non-negligible. Due to its noninvasive nature, relatively low cost and low radiation exposure, a further increase of the utilization of CCTA may be expected which may consequently be paralleled by an in- 
creasing absolute number of incidentally detected CAAs. Hence, awareness of the main issues and possible management strategies regarding CAAs are of importance for every treating physician.

As discrimination between ACAOS and CAD related perfusion defects, especially in middle-aged patients may be difficult, Chapter 2.3 focused on investigating the value of hybrid CCTA/ single photon emission tomography myocardial perfusion imaging (SPECTMPI) in patients with ACAOS and possible concomitant CAD. We retrospectively identified 46 middle-aged patients with ACAOS revealed by CCTA who underwent additional SPECT-MPI. CCTA/SPECT-MPI hybrid imaging findings (ischemia or scar) were analyzed according to the territory subtended by an anomalous vessel or a stenotic coronary artery. Myocardial ischemia or scar was found only in patients who had concomitant obstructive CAD in the vessel matching the perfusion defect as evidenced by hybrid CCTA/SPECT imaging. Hybrid CCTA/SPECT-MPI represents a valuable non-invasive tool to discriminate the impact of ACAOS from concomitant CAD on myocardial ischemia. Our results suggest that in a middle-aged population myocardial ischemia due to ACAOS per se may be exceedingly rare and is more likely attributable to concomitant CAD.

Chapter 2.4 describes the value of fused cardiac hybrid imaging with CCTA and positron emission tomography myocardial perfusion (PET-MPI) in patients with complex coronary artery anomalies (CCAAs). In this retrospective, single center study, seven consecutive patients with CCAAs who underwent clinically indicated hybrid CCTA/PET$\mathrm{MPI}$ in our clinic were included. The findings from both modalities and fused cardiac hybrid imaging were evaluated in these patients. Out of the seven patients with CCAAs, two had Bland-White-Garland anomaly, two showed a coronary artery fistula, two showed a "single right" and one patient showed a "single left" coronary artery. Semiquantitative fused hybrid CCTA/PET-MPI depicted inferolateral scar matching the territory of a non-anomalous vessel with significant concomitant CAD in one patient only. By contrast, analysis of quantitative myocardial blood flow (MBF) as assessed by fused hybrid CCTA/PET-MPI revealed abnormally reduced flow capacities in the territories subtended by the anomalous vessels in four patients. In this case series of middle-aged patients with CCAA, perfusion defects as assessed by semi-quantitative PET-MPI were rare and attributable to concomitant CAD rather than to the anomalous vessel itself. By contrast, impaired MBF as assessed by quantitative hybrid CCTA/PET-MPI was revealed in the majority of patients in the vessel territories subtended by the anomalous coronary artery itself. Fused hybrid CCTA/PET-MPI incorporating information on morphology and on semi-quantitative and quantitative myocardial perfusion may provide added value for the management of patients with CCAA.

As CCTA is a primary investigative tool in patients with CAAs to describe the anatomic high-risk features, reduction in radiation dose and contrast agent would be preferable. We therefore aimed to evaluate in Chapter 2.5 the impact of the latest CCTA techniques allowing a radiation- and contrast-sparing protocol on image quality by 256-slice CCTA using prospective electrocardiogram triggering. Consecutive patients for CAD 
exclusion were included. Tube voltage, tube current as well contrast agent volume and flow rate were adapted to body mass index. Signal intensity was measured by placing a region of interest in the aortic root, the left main artery, and the proximal right coronary artery. Two independent blinded readers semi-quantitatively assessed the image quality regarding motion, noise, and contrast on a four-point scale. Median contrast agent volume and median effective radiation dose were $35 \mathrm{~mL}$ and $0.5 \mathrm{mSv}$, respectively. This study showed that a radiation- and contrast-sparing protocol for CCTA on a latest generation 256-slice computed tomography scanner yields diagnostic image quality of coronary arteries in daily clinical routine.

The prevalence and incidence of CAAs is not negligible. Although in our autopsy study sport-related SCD due to underlying CAAs, specifically ACAOS are rare, it seems that a certain risk for adverse cardiac events remains. Non-invasive cardiac imaging with the use of CCTA play a key role in detecting and diagnosing CAAs. Our new CCTA protocols help to reduce the exposure to radiation and contrast agent in these patients. It is important to exactly describe the anatomic high-risk features and based on our studies to also identify patients with ischemia/scar related to CAAs. The different cardiac imaging modalities such as hybrid CCTA/SPECT-MPI or CCTA/PET-MPI, especially in middleaged patients with possible concomitant CAD, allow to differentiate whether ische$\mathrm{mia} / \mathrm{scar}$ are related to anomalous vessels or CAD. This might have an important impact on further treatment decision making. The possible benefits from surgical correction and sport restriction should be prudently balanced against the risk of an operation and the negative effect of not exercising. Therefore, decision should only be made after integrating all clinical and imaging information as well as discussion of the potential risks and benefits with the patient. 



\section{Samenvatting (Summary in Dutch)}

In de introductie wordt een overzicht gegeven van bekende coronair anomalieën (CAA's), de mogelijke gevolgen van CAA en methoden van non-invasieve beeldvorming. CAA's vallen onder aangeboren cardiale afwijkingen, en kunnen worden verdeeld in anomalieën met een afwijkende oorsprong, verloop of terminatie van een coronairarterie. De prevalentie van CAA's in de algemene populatie is laag en wordt geschat op circa 1 procent. Aangezien de meeste mensen met een CAA asymptomatisch zijn, blijven ze vaak onopgemerkt. Sommige CAA varianten (oorsprong coronairarterie uit de tegenovergestelde sinus van Valsalva, ACAOS) kunnen symptomatisch zijn, met ongewenste, cardiale manifestaties. Vooral jonge atleten met een ACAOS hebben een verhoogd risico op sport-gerelateerde, plotse hartdood (SCD). Naast jonge atleten met een CAA, worden CAA's in toenemende mate ontdekt bij mensen van middelbare en oudere leeftijd. Dit is te verklaren door toenemende gebruik van non-invasieve beeldvorming van de coronairarteriën om coronarialijden (CAD) uit te sluiten. Dit wetenschappelijk proefschrift onderzoekt en beschrijft de incidentie van sport-gerelateerde, plotse hartdood bij CAA's en de rol van non-invasieve beeldvorming bij screening en behandeling.

In Hoofdstuk 2.1 wordt sport-gerelateerde, plotse hartdood bij jonge atleten onderzocht en de resultaten beschreven. De incidentie, karakteristieken, en onderliggende oorzaken van sport-gerelateerde, plotse hartdood waronder CAA's worden beschreven. Hiervoor werd een retrospectieve analyse verricht aan de hand van forensische rapporten van sport-gerelateerde, plotse hartdood bij jonge, Zwitserse atleten. Deze data werd vervolgens vergeleken met gegevens van de algehele Zwitserse populatie. In totaal waren er negenenzestig gevallen van sport-gerelateerde, plotse hartdood, waarbij bij obductie coronarialijden de meest voorkomende onderliggende pathologie betrof, gevolgd door hypertrofische cardiomyopathie en 'alledaagse nietspecifieke bevindingen'. In tegenstelling tot andere studies werd CAA in onze studie minder frequent gevonden. In deze studies werd namelijk aangetoond dat na de hypertrofische cardiomyopathie, juist CAA de op een na meest voorkomende oorzaak was van sport-gerelateerde, plotse hartdood. Onze bevindingen komen overeen met recentere studies, die ook aantonen dat de prevalentie van CAA bij sport-gerelateerde plotse hartdood mogelijk wordt overschat.

In Hoofdstuk 2.2 beschrijven we de resultaten van een retrospectieve, single-center studie waarin de prevalentie, incidentie en karakteristieken van CAA gedetecteerd bij coronair computer tomografie angiografie (CCTA) wordt onderzocht. Bij 145 van 5634 opeenvolgende patiënten die waren verwezen voor CCTA, werd een CAA gediagnosticeerd. Dit resulteerde in de geobserveerde periode, in een prevalentie van $2.6 \%$ en een cumulatieve incidentie van 2.1\%. De prevalentie van bij CCTA gedetecteerde CAA's is derhalve niet verwaarloosbaar. Doordat CCTA een non-invasieve vorm van 
beeldvorming is, met relatief lage kosten en stralingsbelasting, is te verwachten dat het in toenemende mate gebruikt zal gaan worden. Hierdoor is de verwachting dat ook het aantal per toeval ontdekte CAA's zal toenemen. Derhalve is het van belang dat iedere behandelaar op de hoogte is van de verschillende CAA's, de prognose en behandeling.

Het onderscheid tussen ACAOS en coronarialijden-gerelateerde perfusiedefecten kan, met name bij patiënten van middelbare leeftijd, moeilijk zijn. Hoofdstuk 2.3 onderzoekt de rol en waarde van hybride CCTA/single photon emissie tomografie myocardiaal perfusie imaging (SPECT-MPI) in patiënten met een ACAOS en verdenking op coronarialijden. We onderzochten 46 patiënten, met een door CCTA vastgesteld ACAOS, die aanvullend een SPECT-MPI ondergingen. De bevindingen van de hybride CCTA/SPECT-MPI-beelden (ischemie dan wel littekenvorming) werden geanalyseerd door de desbetreffende coronair anomalie of obstruerende coronairarterie te relateren het stroomgebied van desbetreffende coronairarterie. Myocardischemie of littekenvorming werd alleen gevonden in patiënten met bijkomstig obstructief coronarialijden van de desbetreffende coronairarterie. Hybride CCTA/SPECT-MPI is dus een waardevolle, non-invasieve methode om te discrimineren tussen myocardischemie o.b.v. een ACAOS of o.b.v. coronarialijden. Onze resultaten suggereren daarmee dat in een patiëntenpopulatie van middelbare leeftijd, myocardischemie veroorzaakt alleen ACAOS uiterst zeldzaam is en vooral wordt veroorzaakt door bijkomstige coronarialijden.

Hoofdstuk 2.4 beschrijft de waarde van hybride, cardiale beeldvorming door middel van een fusie van CCTA en positron emissie tomografie myocardiaal perfusie imaging (PET-MPI) in patiënten met complexe coronair anomalieën (CCAA's). In deze retrospectieve, single-center studie werden in totaal 7 patiënten met een CCAA geïncludeerd, met een klinische indicatie voor hybride CCTA/PET-MPI. De bevindingen van individuele en gefuseerde, hybride beelden werden geëvalueerd. Van de 7 patiënten met een CCAA, hadden twee een Bland-White-Garland anomalie, twee een coronaire fistel, twee enkel een rechter coronairarterie en één enkel een linker coronairarterie. Een semi-kwantitatieve analyse van de gefuseerde, hybride CCTA/PET-MPI beelden toonde slechts bij één patiënt littekenvorming inferolateraal, overeenkomend met het stroomgebied van een normale verlopende coronairarterie waarin bijkomstig stenostisch coronarialijden. Kwantitatieve analyse van de myocardiale perfusie (MBF) toonde een afgenomen perfusiecapaciteit in de stroomgebieden van de coronair anomalieën van vier patiënten. Perfusiedefecten werden alleen gezien bij semi-kwantitatieve analyse van de gefuseerde, hybride CCTA/PET-MPI-beelden en toe te schrijven aan bijkomstig coronarialijden. Een verminderde MBF in het stroomgebied van de desbetreffende coronair anomalie werd in de meerderheid van de patiënten aangetoond. Hybride CCTA/PET-MPI waarbij zowel morfologische informatie als informatie over (semi-)kwantitatieve myocardiale perfusie wordt verkregen, kan van toegevoegde waarde zijn bij de behandeling van CCAA.

Vanwege het feit dat CCTA uitermate geschikt is als primaire onderzoeksmethode om hoog risico kenmerken in patiënten met CAA's te beschrijven, is het van belang de 
bestralingsbelasting en de hoeveelheid contrastvloeistof te reduceren. In Hoofdstuk 2.5 wordt m.b.v. de meest recente CCTA technieken die bestralingsbelasting en contrastmiddel reduceren de beeldkwaliteit van een 256-slice CCTA met prospectieve, elektrocardiogram triggering onderzocht. Opeenvolgende patiënten verwezen voor het uitsluiten van coronarialijden werden geïncludeerd. Het voltage en de spanning van de röntgenbuis, alsmede de hoeveelheid contrastvloeistof en de snelheid van de injectie (flow rate) werden aangepast o.b.v. lichaamsgewicht van de patiënt. De signaalintensiteit werd gemeten in de aortawortel, de linker coronairarterie en de rechter coronairarterie. De beeldkwaliteit werd door twee onafhankelijke, beoordelaars beoordeeld op beweging, ruis en contrast, gebruikmakend van een vierpuntenschaal. Het mediane volume van de gebruikte contrastvloeistof en de mediane bestralingsbelasting waren respectievelijk 35 milliliter en $0.5 \mathrm{mSv}$. Deze studie toont aan dat een CCTA protocol met een gereduceerde bestralingsbelasting en hoeveelheid contrastvloeistof op een een 256-slice CCTA, in staat is een diagnostische beeldkwaliteit te produceren voor het afbeelden van de coronairarteriën in de dagelijkse kliniek.

De prevalentie en de incidentie van CAA's in niet verwaarloosbaar. Hoewel in onze obductiestudie bij sport-gerelateerde plotse hartdood door ACAOS slechts zelden voorkomt, lijkt het risico op ongewenste, cardiale manifestaties bij CAA toch verhoogd. Non-invasieve beeldvorming door middel van CCTA speelt een belangrijke rol in het detecteren en diagnosticeren van CAA's. Onze moderne CCTA protocollen en technieken kunnen de hoeveelheid contrastmiddel en stralingsbelasting reduceren, zonder dat dit ten koste gaat van de diagnostische kwaliteit. Verder is het belangrijk om de anatomische en hoog risico kenmerken te beschrijven en patiënten met ischemie en/of littekenvorming t.g.v. CAA's te identificeren. Onze studies tonen aan dat m.b.v. hybride CCTA/SPECT-MPI of CCTA/PET-MPI het mogelijk is te differentiëren tussen ischemie en/of littekenvorming bij patiënten van middelbare leeftijd door obstructief coronarialijden of door een CAA. Deze differentiatie heeft belangrijke gevolgen voor de behandelingsstrategie. Desalniettemin zouden de mogelijke positieve effecten van chirurgisch ingrijpen/correctie van de anomalie en een sportverbod opgewogen moeten worden tegen het risico van een operatie en de negatieve effecten van inactiviteit. De uiteindelijke beslissing kan daarom pas worden genomen na verzameling van alle klinische informatie, optimaal afbeelden van de anomalie en kritische bespreking van de voor-/ en nadelen van operatief ingrijpen met de patiënt. 
